\title{
The Royal Institution of Naval Architects
}

Maritime Project Management

24-25 February 2016, London, UK

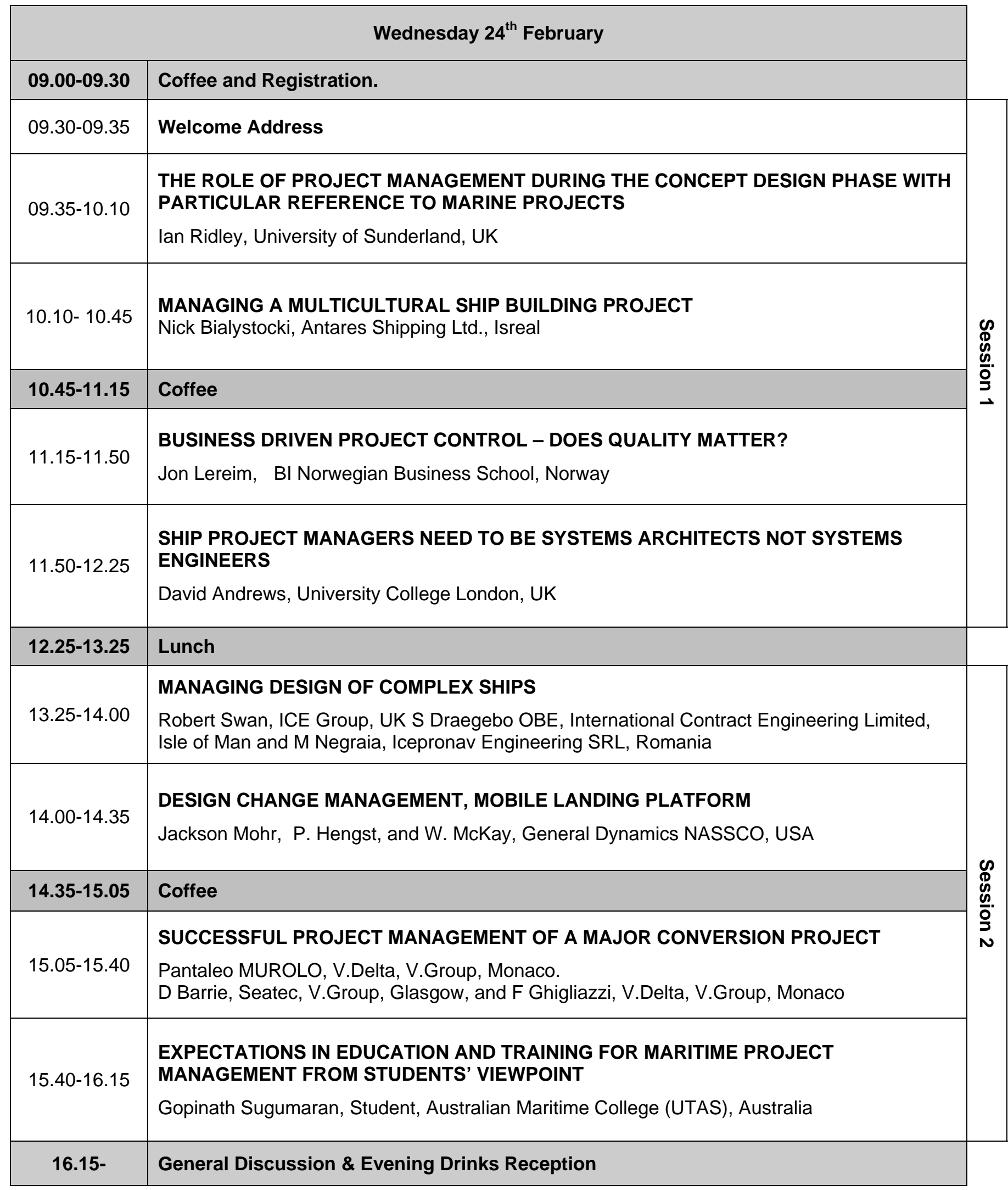

